\title{
Queensland University of Technology
}

\author{
Mark Piccini
}

The excess of life and death in Roberto Bolaño's 2666 and Horacio Castellanos Moya's Senselessness

\begin{abstract}
:
This paper examines two novels, both published in 2004 and later translated into English: 2666 by Chilean writer Roberto Bolaño and Senselessness by HonduranSalvadoran writer Horacio Castellanos Moya. Bolaño and Castellanos Moya write death and dying as a global concern and place readers in the global North at the centre of events that happened, or are happening, in the South. This paper argues that 2666 and Senselessness express the human potential in desire for, and to create, excess, universalising guilt against a tendency to contextualise or localise events of mass murder in Central and South America. Both novels represent death and dying while expressing an uncanny excess of life at the level of form and content. Bolaño and Castellanos Moya bombard the reader with the details of crimes and harrowing witness testimonies in their novels, but deny the reader closure or the ability to mourn the dead. Instead, the excess of life traces a void that, according to French psychoanalyst Jacques Lacan and others, is at the centre of the subject of desire. It is at the level of desire that we can locate ourselves in both novels and understand our part in the events of mass murder their writers narrate.
\end{abstract}

\section{Biographical note:}

Mark Piccini is a sessional academic in the Creative Writing and Literary Studies Department at Queensland University of Technology, where he is in the final year of his $\mathrm{PhD}$. His research interests are Lacanian psychoanalysis and representations of global violence in late twentieth- and twenty-first-century Latin American literature, particularly in the work of Roberto Bolaño.

\section{Keywords:}

Creative writing - Death - Latin American literature - Psychoanalysis - Bolaño Castellanos Moya 


\section{Introduction}

Whether the topic is Colombian drug lord Pablo Escobar and his Medellín Cartel, sicarios or hitmen employed by Colombian and now Mexican cartels, or narcoculture in general, books, movies and television shows about Latin America tend to magnify life, death and the violence that brings life and death into contact. The two writers discussed in this paper have achieved international recognition. They are both Latin American and are concerned with representing violent death and dying in that part of what is known as the global South. North and South is a dichotomy replacing earlier conceptions of the First and Third Worlds that recognises complex neo-colonial power imbalances and is better suited to a discussion of writing from the Americas than East and West. In the two novels that are the subject of this article, neither writer confines violence to a place of exception, to Mexico, Central or South America. Their writing shows that even though violence in the South is often heightened by economic and social pressures, it is not ontologically distinct from violence in the North.

Matthew Heineman's 2015 documentary film Cartel Land looks at two responses to the drug violence in Mexico, one by citizens of the west-central Mexican state of Michoacán and the other by Americans along the Arizona border. The film's opening credits roll, and the camera takes an aerial shot of the Mexico-United States barrier as it cleaves an otherwise continuous landscape of mesquite thickets. The voice of Tim 'Nailer' Foley says, 'There's an imaginary line out there between right and wrong, good and evil'. The official synopsis tells us that Foley 'heads a small paramilitary group called Arizona Border Recon, whose goal is to stop Mexico's drug wars from seeping across our border'. Foley continues, 'I believe what I am doing is good, and what I am standing up against is evil'. Foley mistakes the border between Mexico and the United States for a border that separates one ontological state of being and another. In reality, the border fence is a staggered series of different fences and those on the other side of it are ordinary people.

This paper looks at two novels published in 2004 and translated into English in 2008, 2666 by Chilean writer Roberto Bolaño and Senselessness by Honduran-Salvadoran writer Horacio Castellanos Moya. Bolaño and Castellanos Moya approach death and dying as a global concern by placing the subject of desire at the centre of events, which universalises guilt against the tendency to contextualise, localise and ultimately exceptionalise events of mass murder in Mexico and Central America. To understand how they appeal to the universal in concrete, historical acts of violence, the below first discusses the French psychoanalyst Jacques Lacan's theory of subjectivity, the Lacanian Other, and the bearing of both on social reality.

\section{The Lacanian (Latin American) Other}

For Freud and Lacan, the subject enters society by way of castration. Lacan understands castration as 'a symbolic act which bears on an imaginary object' (Evans 1996: 23). The Lacanian name for this imaginary object is the objet a. It does not exist in reality and so appears in fantasy. For Slavoj Žižek, fantasy and reality work together to form 'a fictional coherence and consistency that appears to fulfil the lack that constitutes social reality' (Cottrel 2014: 90). Clinical psychoanalysis seeks to 
understand and affect how individual human beings organise their enjoyment; that is, how they desire the objet $a$ without realising that what they lost in castration never actually existed. Psychoanalytic cultural theory and the practice of psychoanalytic literary criticism aim at what Žižek calls 'the thick symbolic texture of knowledge, expectations, prejudices, and so on' (2010: 338) through which groups of people organise their enjoyment.

Lacan calls this repository of knowledge the 'big Other', the order of language that organises the subject's being-in-the-world by allowing it to pursue the objet a. Elizabeth Wright points out that the Lacanian Other 'is not the Other of discourses such as social anthropology and cultural studies' (2000: 37):

The [Lacanian] Other is not so much that which determines reality and directs our choices, but a structure that works through a constitutive lack via a promise it cannot fulfil. Hence the Other works through a kind of deceit which, if not recognised and capitalised upon, has catastrophic results for self and society (37-38).

The Other of cultural studies and social anthropology works through a kind of deceit that magnifies the differences of a group of people to such an extent that they are perceived as ontologically inferior to another group. The Other of psychoanalysis works through the constitutive lack by helping the subject reframe it as loss, which results in the fantasy that another (uncastrated) subject has (found, stolen) what I have lost.

Lacan implies the adverse effects on self and society of this kind of deceit when discussing envy in his eleventh seminar. He describes 'the envy that makes the subject pale before the image of a completeness closed upon itself, before the idea that the petit $a$, the separated $a$ from which he is hanging, may be for another the possession that gives satisfaction' (1977: 116). Adam Cottrel emphasises the catastrophic implications of this logic:

The logic of fantasy in relation to lack suggests that, if I am lacking, it is because some other nefarious figure has stolen it, and thus the lack of lack, as it were, becomes an object of possession under capitalism. This rendering is consistent with Žižek's assertion that fantasy leads to all varieties of discrimination: racism, ageism, and homophobia, among others (2014: 91).

Because psychoanalysis universalises the experience of castration it imposes a negative ontology and denies the ontological assumptions at work in the process of cultural othering, which turns some feature of a culture into its essential trait. In psychoanalytic terms, this essential feature fulfils the Other and excludes them from the community of subjects whose desire constitutes social reality as a search for fulfilment. In all of this, the Other appears to be an excess of life. However, this is not the case.

The excessive enjoyment or jouissance of the Other is the excess of life referred to in the title of this paper. Lacan's term jouissance is often translated in English as 'enjoyment' but jouissance exceeds the notion of enjoyment as the state or process of taking pleasure in something. Néstor Braunstein (2003: 104) writes that jouissance 'is a "something" lived by a body when pleasure stops being pleasure. It is a plus, a 
sensation that is beyond pleasure'. He continues: 'Let us be clear: the jouissance of the Other is not in the Other [...] but in the subject himself' (2003: 111). Bolaño and Castellanos Moya accomplish a redistribution of jouissance and reverse the way that the North organises its enjoyment in regards to death and dying. Both 2666 and Senselessness are set in the context of a regional violence, but they eschew context in order to point to a universal human potential and facilitate global participation in a form of violence.

\section{Bolaño and 2666}

The bulk of 2666 takes place between 1993 and 1997, in and around the MexicoUnited States border city Santa Teresa, Bolaño's nom de guerre for Ciudad Juárez, which is the largest city in the Mexican State of Chihuahua. Juárez is the southern half of a binational metropolitan area. Just across the Rio Grande from Juárez is the northern half of the city: El Paso in Texas. Last year, Washington-based CQ Press ranked El Paso the safest city of its size in the United States, a title it has held since 2011. The year before El Paso was first honoured, 3,111 homicides were reported in Juárez (Volk 2015: 22), making the city the murder capital of the world for the third year in a row (Gillman and Jochum 2015: 4). This paradox, a city split between life and death, is sustained by a libidinal investment in the million-odd people who live in Juárez as the Other. This is the indirect target of Bolaño's criticism in 2666.

The image of an (uncastrated, non-lacking) Southern Other baying at the gates fulfils the lack that constitutes the (castrated, lacking) North. This exemplifies Lacanian envy, which Žižek politicises and calls jealousy, bringing all varieties of discrimination together for analysis as ways of organising our enjoyment:

In jealousy, the subject creates/imagines a paradise (a utopia of full jouissance) from which he is excluded. The same definition applies to what one can call political jealousy, from anti-Semitic fantasies about the excessive enjoyment of the Jews to Christian fundamentalists' fantasies about the weird sexual practices of gays and lesbians (2010: 81, emphasis in original).

As Cottrel notes, imagining the excessive enjoyment of the Other 'opens the possibility of a violence predicated on destroying the enjoyment we fantasize this Other to possess at our expense' (2014: 91). Such violence takes two forms: what Žižek calls "directly visible "subjective" violence, violence performed by a clearly identifiable agent', to which he opposes objective violence: '[O]bjective violence is precisely the violence inherent to [the] "normal" state of things' (2009: 1-2).

In one of the last interviews before his death in 2003, Bolaño was asked what he thought hell would be like. He replied, 'Like Ciudad Juárez, which is our curse and our mirror, the unquiet mirror of our frustrations and of our vile interpretation of our freedom and of our desires' (2011: 365-66). This paper argues that, with 2666, Bolaño holds an unquiet mirror up to the world and places the North at the centre of events that happened, or are happening, in the South, on the other side of the world or, in the case of the Juárez, next door. 
The fourth and largest of the five parts that make up 2666 is called 'The Part about the Crimes'. The eponymous crimes are the killings of women in Santa Teresa: the bodies of 109 women are found in the fourth part of 2666 and Chris Andrews writes that 'their number exactly matches that of the real victims in Juárez in the years 19951998' (2014: 229, emphasis in original). Moreover, Andrews indicates: 'Seventythree correspondences between fictional cases and real cases' (2014: 229) noting, however, that 'some of the correspondences are based on a single common feature, which may be simply coincidental' (2014: 229). Bolaño spent his teenage years and early twenties in Mexico City, but never visited Juárez in his lifetime. His fidelity to the harrowing details of the epidemic is partly the result of the author's collaboration with journalists on the ground in Juárez.

In an article that places 2666 firmly in the context of investigative journalism, Marcela Valdes tells the story of Mexican journalist Sergio González Rodríguez who, in 1995, began to cover the killings in Juárez, culminating in the publication in 2002 of his book Huesos en el desierto (Bones in the Desert). Valdes interviewed González Rodríguez, who said that Bolaño 'needed [...] help with the details of the murders and the police investigations' (2008: 20). Valdes also quotes González Rodríguez saying that 'the savage detective [Bolaño] wanted the other savage detective, who is me, to draw analogous conclusions' (2008: 20). Both novelist and journalist construct a picture of life and death along Mexico's northern border. This, however, is far from the end of the story that is told in Bolaño's fictional representation of death and dying.

The first act of subjective violence in 2666 has, it seems, nothing to do with the femicide and no bearing on the progression of the narrative towards the crimes at the heart of the novel. Peter Boxall writes that 'Santa Teresa emerges as a kind of hub, a place at the border or threshold, where the subterranean connections that bind the world together are made visible' (2013: 193). In the first part of 2666, 'The Part about the Critics', it is clear that (the) jouissance (of the Other) is a subterranean connection binding the world together in constellations of disunity.

In 'The Part about the Critics', Bolaño describes a series of circumstances by which the femicide begins to affect an incestuous group of Western European academics known as the Archimboldians. A love triangle forms between three of them (Liz Norton, Jean-Claude Pelletier and Manuel Espinoza) and is circuitously satisfied by an act of ethnic violence on the streets of London. When a Pakistani taxi driver accuses the Europeans in general, and Norton in particular, of indecency, Pelletier and Espinoza beat him nearly to death while Norton pleads for them to stop. After the assault, Pelletier and Espinoza convince one another 'that it was the Pakistani who was the real reactionary and misogynist, the violent one, the intolerant and offensive one' (80). Žižek writes that what is aimed at in violence, ethnic violence or the gender violence that is the focus of 'The Part about the Crimes', is the objet a: 'At its most radical level, violence is precisely an endeavour to strike a blow at this unbearable surplus-enjoyment contained in the Other' (2005: 236). Pelletier and Espinoza, offended by the driver's misogyny, nevertheless imagine Norton as a kind of femme fatale. Repeatedly referring to Norton as 'the Gorgon/Medusa' $(76,80)$, they insert themselves into what Žižek calls: 'The standard heterosexual "fatal attraction" scene', which 'is that of male desire captivated and fascinated by a deadly jouissance 
féminine' (1999: 304). From the moment the two men fall in love with Norton, she is no longer one of the Archimboldians but the Other.

Renata Salecl writes that 'hatred is always the counterpart of love' (1998: 52), and continues: 'A man falls in love with a woman because he perceives in her something that she actually does not have, the object $a$, the object cause of desire' (68). Norton, Pelletier and Espinoza arrive in Santa Teresa after a young Mexican conference-goer tells them that the reclusive German author whose work forms the basis of their scholarship is there. They stay at a place called the Hotel Mexico and Unlike Pelletier's or Espinoza's room, Norton's contains a second mirror. On their first night in Santa Teresa, Norton has a dream in which she stands in the room at the point where she can see herself in both mirrors:

All at once Norton realized that the woman reflected in the mirror wasn't her. [...] The woman's eyes were just like her eyes. The cheekbones, the lips, the forehead, the nose. Norton started to cry in sorrow or fear, or thought she was crying. She's just like me, she said to herself, but she's dead (Bolaño 2008: 116),

In her dream, the mirror is the unquiet mirror of Pelletier and Espinoza's (vile) interpretation of love. Pelletier and Espinoza imagine Norton as the Gorgon whose gaze turns men to stone, but it is their desire for the objet $a$ that announces itself in the mortified image of Norton: the first dead woman in 2666.

The femicide reifies Norton's dream, but her dream is a space in the context of the femicide for the subject in whom the jouissance of the Other resides. Žižek writes that 'it is in dreams that we encounter the Real. It is not that dreams are for those who cannot endure reality; reality itself is for those who cannot endure (the Real that announces itself in) their dreams' (2007: 222). 2666 differs from Huesos en el desierto in the scale of the image Bolaño is able to reflect in the unquiet mirror of Santa Teresa. Like the journalist González Rodríguez, Bolaño collects and relays information about crime scenes with such accuracy that Andrews is able to match almost all of them to their real-world equivalents (2014: 229). Around these sections of artless testimony and forensic detail are sequences that flow through dreamlike states, in which characters confront the abyssal foundations of violence. 2666 is bookended by the presence of death and dying in places far from northern Mexico and times before the decade leading to the new millennium. In the first part of 2666, Pelletier and Espinoza scour London's newspapers the day after the incident with the taxi driver, worried that they might have killed him. In the last part of the novel, a trainload of Greek Jews are sent to their deaths during the unparalleled horrors of the Holocaust.

\section{Castellanos Moya and Senselessness}

Senselessness, on the other hand, discusses the massacres of the indigenous peoples of Guatemala during its 36-year civil war. Specifically, Castellanos Moya refers to the atrocities recorded in the report Guatemala: Nunca Más (Guatemala: Never Again) that was compiled by the Human Rights Office of the Archdiocese of Guatemala and published in April 1998. The unnamed narrator-protagonist of Senselessness is a sex- 
obsessed writer from El Salvador who, desperate for money, agrees to copyedit 1,100 pages of the report despite having little interest in or sympathy for the victims. The narrator's only friend in Guatemala warns him that 'editing one thousand one hundred pages of stories about Indians obsessed with terror and death could break even the strongest of spirits' (19). Most scholars agree that the narrator's resistance to empathy is tested during Senselessness, but if the narrator's obsession with the stories testifies to his empathetic identification with the victims, it also bears witness to the jouissance of the Other.

Working for the archdiocese, the narrator is fascinated with the enjoyment that transformed soldiers into rapists and torturers and exceeds the limits of his job as a copyeditor. At one point, for example, he decides to turn the case of an unfortunate civil registrar who was tortured and killed by machete-wielding soldiers into a story. This story 'would begin at the precise instant the lieutenant, with one stroke of his machete, split open the head of the civil registrar' (61). Afterwards, the narrator says that the registrar's ghost 'would start to tell his story, always with the fingerless palms of his hands pressing together the two halves of his head to keep his brains in place, for I am not a total stranger to magical realism' (61). In his story, the narrator would magnify the reality of violence whereas elsewhere in Senselessness, Castellanos Moya does not exaggerate events that took place in Guatemala, but, as Frans Weiser points out, takes the testimony of victims 'virtually verbatim' (2009: 4) from Guatemala: Nunca Más. Castellanos Moya made his opinion of magical realism clear during an interview with the online magazine Guernica, in which he gave the following as justification for the perceived turn away from the genre in Latin America: 'Our reality has not been magical' (2009). In this, Castellanos Moya is similar to Bolaño, who said of Latin Americans that 'we're reasonable human beings (poor, but reasonable), not spirits out of a manual of magic realism, not postcards for foreign consumption and abject national masquerade' (2011: 106). The sentiment of both writers is expressed in the way they write not only death, but violence emerging on a street in central London in the first part of 2666 and, as we shall see, in Germany at the end of Senselessness.

Twice towards the end of Senselessness, the narrator is perturbed by the image of soldiers killing an infant, '[A]n image that occurred several times in the report and that little by little invaded me until it had taken complete possession of me, at which point I stood up and began to pace around the small space of my room' (125). He goes into a kind of trance and when he comes to, he finds himself 'in the middle of the room, shaking, sweating, a little dizzy because of the vertiginous movements of swinging the baby over my head' (126). Again, jouissance is 'a "something" lived by a body when pleasure stops being pleasure' (Braunstein 2003: 104). The narrator's psychosis makes clear that the jouissance of the Other is not in the Other but in the narrator himself. Shortly after this incident, the narrator flees Guatemala for Germany, where he imagines meeting an infamous Guatemalan general while drinking at a bar. The narrator is trying to avoid looking in the mirror behind the bar, but cannot help himself. That is, until the narrator realises to his amazement that leaning against the bar to his right is the general whose name appears throughout the 1,100 pages of the report in connection with the most heinous crimes. 
Crimes are central to 2666 and Senselessness, but neither novel is easily identifiable as belonging to the genre of crime fiction. I have argued elsewhere (Piccini 2015) that 2666 subverts a certain expectation of crime fiction and the detective story in particular. Many characters in 2666 try to make sense of the killings of women in Santa Teresa. Journalist and activist Oscar Fate proposes, for example, 'A sketch of the industrial landscape in the third world, [...] a serious crime story' (295). Though he finds himself in the middle a group of men who are at the very least complicit in the exploitation and killing of women, he never puts pen to paper. Similarly, American criminologist Albert Kessler, a 'modern-day Sherlock Holmes' (610), is set to deliver a lecture at the University of Santa Teresa, where a crowd has gathered to see a 'scientific miracle, the miracle of the human mind set in motion' (610). Unlike Kessler's audience, the reader does not expect a miracle. In the third part of 2666, which takes place after the events of the fourth part have happened, Kessler is on his way home following a second visit to Santa Teresa and tells a colleague: 'I tried to help, but the situation was impossible' (267). Žižek writes, 'The role of the detective [in the detective story] is [...] precisely to dissolve the impasse of [...] universalized, free-floating guilt by localizing it in a single subject and thus exculpating all others' (1991: 59). As 'The Part about the Critics' shows, Bolaño writes death in a way that refuses to exclude subjects from guilt on the grounds of history, context, location or even their psychological profile.

It seems like madness or the eponymous senselessness, but at the end of Castellanos Moya's novel the narrator avoids responsibility for his jouissance by creating an Other onto whom to project it. The narrator shouts at the general, accusing him of being a torturer, an assassin, and a spy (140). Using Žižek's work on detective stories, the scene can be read as an attempt by the narrator to act like a detective and resolve the impasse of his involvement in violence at the level of desire. Žižek writes that 'the detective's "solution" is [...] nothing but a kind of realized hallucination. The detective "proves by facts" what would otherwise remain a hallucinatory projection of guilt onto a scapegoat' (1991: 59). Castellanos Moya is careful to call attention to the weakness of the Other by which his narrator exculpates himself: the man, supposedly a general in the Guatemalan army, does not understand Spanish and responds to the narrator's accusations in German. The narrator finds himself in the heart of the North when he achieves self-absolution in such a farcical way. His 'solution' is not a solution for the reader, but Castellanos Moya's message for those who might put the novel back in the context of Latin American violence.

\section{Conclusion}

At the same time as 2666 and Senselessness refer to concrete examples of mass murder, they are narrated by or tell stories of people from around the world who participate in violence at the level of desire. In response to writers like Bolaño and Castellanos Moya, writers from the North must reach for what is not historical and not contextual when they represent violent death and dying that happens at home and abroad, in the past and present. At the same time, they should make every effort to decry concrete examples of injustice. Today's fortification of borders relies, implicitly 
or explicitly, on the way that people's individuality is obfuscated by images of the essential traits that constitute them as groups. Beneath the varieties of discrimination against certain groups is the image of the Other's unrestricted access to jouissance, but insofar as this image screens out the lack that constitutes subjectivity and social reality, it is the subject who enjoys it and the objectified subject who suffers it. It is crucial to see ourselves in the unquiet mirror of the Other so that, instead of Others, we see other subjects with whom we can empathise.

\section{Works cited}

Andrews, Chris 2014 Roberto Bolaño's Fiction: An Expanding Universe, New York: Columbia UP Bolaño, Roberto 2008 [2004] 2666, N Wimmer (trans), London: Picador

Bolaño, Roberto 2011 [2004] Between Parentheses, N Wimmer (trans), I Echevarría (ed), London: Picador

Boxall, Peter 2013 Twenty-First-Century Fiction: A Critical Introduction, Cambridge and New York: Cambridge UP

Braunstein, Néstor A 2003 'Desire and jouissance in the teachings of Lacan' in J-M Rebaté (ed) The Cambridge Companion to Lacan, Cambridge and New York: Cambridge UP, 102-15

Castellanos Moya, Horacio 2008 [2004] Senselessness, K Silver (trans), New York: New Directions

Castellanos Moya, Horacio in interview with Wes Enzinna 2009 'Our Reality Has Not Been Magical' Guernica 9 April, at https://www.guernicamag.com/interviews/our_reality_has_not_been_magic (accessed 3 August 2016)

Cottrel, Adam 2014 'Fantasy' in R Butler (ed) The Žižek Dictionary, Durham: Acumen, 89-92

CQ Press 2014 'City Crime Rankings 2014: Rankings by Population Categories', at http://os.cqpress.com/citycrime/2013/2014_CityCrimeRankingsbyPopulation.pdf (accessed 3 August 2016)

Evans, Dylan 1996 An Introductory Dictionary of Lacanian Psychoanalysis, London and New York: Routledge

Gillman, Laura and Tobias Jochum 2015 'New Interdisciplinary Perspectives on Feminicide at the U.S.-Mexico Border’ FIAR: Forum for Inter-American Research 8 (2), 4-19

Heineman, Matthew 2015 Cartel Land, New York: Our Time Projects and The Documentary Group Lacan, Jacques 1977 [1973] The Four Fundamental Concepts of Psychoanalysis, J-A Miller (trans), New York and London: WW Norton

Piccini, Mark 2015 'The Secret of the World Remains Hidden: Roberto Bolaño as an Antiliterary Author' Transnational Literature 8 (1), 1-11

Salecl, Renata 1998 (Per)versions of Love and Hate, London and New York: Verso

Valdes, Marcela 2008 'Alone Among the Ghosts: Roberto Bolaño's 2666' The Nation 19 November, at http://www.thenation.com/article/alone-among-ghosts-roberto-bolanos-2666 (accessed 3 August 2016)

Volk, Steven S 2015 'The Historiography of Feminicide in Ciudad Juárez: Critical and Revisionist Approaches' FIAR: Forum for Inter-American Research 8 (2), 20-45

Weiser, Frans 2011 'Present-ing the Past: The Historicized Turn in Horacio Castellanos Moya's Senselessness' Otherness: Essays and Studies 2 (1), 1-16

Wright, Elizabeth 2000 Lacan and Postfeminism, Cambridge: Icon

Žižek, Slavoj 1991 Looking Awry: An Introduction to Jacques Lacan through Popular Culture, Cambridge, Massachusetts: MIT 
Žižek, Slavoj 1999 The Ticklish Subject: The Absent Centre of Political Ontology, London and New York: Verso

Žižek, Slavoj 2005 Interrogating the Real, R Butler and S Stephens (eds), London and New York: Continuum

Žižek, Slavoj 2007 'Psychoanalysis and the Lacanian Real: "Strange shapes of the unwarped primal world"” in M Beaumont (ed) Adventures in Realism, Malden and Oxford: Blackwell

Žižek, Slavoj 2009 Violence: Six Sideways Reflections, London: Profile

Žižek, Slavoj 2010 Living in the End Times, London and New York: Verso 